\title{
CONSTITUTIONAL IMMUNITY CLAUSE AND THE FIGHT AGAINST CORRUPTION IN NIGERIA
}

\author{
Sesan Fabamise*
}

\begin{abstract}
One of the most pressing debates in Nigeria today is on the continued retention, or removal, of the immunity clause enshrined in section 308 of the 1999 Constitution of the Federal Republic of Nigeria. Some scholars canvass for the removal of the immunity clause because its retention, they argue, appears ironic in view of the stance of the government to rid governance of corrupt practices, including misappropriation of public funds. Others have called for its retention while another set of scholars further ask that it be extended to the leadership of the National Assembly and the States Houses of Assembly. This latter group has said that the Senate President, the Deputy Senate President, the Speaker of the House of Representatives and the Deputy Speaker as well as the Speakers of the States Houses of Assembly and their Deputies should be granted immunity under the Constitution. This article discusses the immunity clause and its sphere, extent and limits as it relates to the officers protected, the arguments for and against its retention in the Constitution, as well as state practices in other jurisdictions.It concludes that it is expedient to retain the clause, but the call in some quarters to expand it to cover the leadership of the National Assembly and States Houses of Assembly is not viable.
\end{abstract}

Keywords: Corruption, immunity, Constitution, sustainable development.

DOI: https://dx.doi.org/10.4314/jsdlp.v8i2.8

\section{INTRODUCTION}

Corruption derives from the Latin word corruptus, which means to break or destroy. ${ }^{1}$ Literally, corruption means to break away, destroy or depart from morality, sound ethics, tradition and civic virtues, law and

* LL.B (Lagos), LL.M (Lagos) Associate Professor and Head of Department, Public and International Law, College of Law, Afe Babalola University Nigeria.

1 Black's Law Dictionary, 8th Edition (Thoins on West-USA, 2004). 
religion. In practice, corruption is any form of unethical, dishonest or illegal conduct by a person in authority, mostly for private gain. ${ }^{2}$ The United States Vision 2010 Committee defined corruption as "all those improper actions or transactions aimed at changing the normal course of events, judgments and positions of trust". ${ }^{3}$ The Committee further listed sixteen forms in which corruption manifests itself in Nigeria. These include advance fee fraud (also known as 419), bribery, extortion, nepotism, favouritism, inflation of contracts, falsification of accounts, perversion of justice by organs administering justice, tax evasion, smuggling and racketeering, money laundering, hoarding adulteration of market goods and denting of measures to reduce their contents with a view to giving advantage to the vendor, abuse of office, foreign exchange swindling and drug trafficking, heinous economic crimes against the state (most of the time in collusion with multinational companies and foreigners) examination malpractices and election malpractices. ${ }^{4}$

Corruption encompasses any act undertaken with the deliberate intent of deriving or extracting monetary or other benefits by encouraging or conniving in an illegal activity. ${ }^{5}$ The benefits of corruption may also be obtained by harassing innocent people through the abuse of power or authority, or authority acquired by an explicit or implicit contract with another party or through a solemn promise to act in good faith.Corruption is also the degeneration in rules and norms of official conduct brought about by the permeating of selfish and unethical consideration in taking decisions by a person in authority knowing that such decisions contravene the rules guiding the behaviour of a person in such position. ${ }^{6}$ Generally speaking, corruption is a departure

2 Daniel Kaufmann and Pedro C. Vicente, Legal Corruption (World Bank Publication, 2005) 1-5 http://siteresources.worldbank.org/INTWBIGOVANTCOR/ Resources/Legal_Corruption.pdf

3 Report of the Committee on Homeland Security and Governmental Affairs United States Senate to Accompany S. 3243 https://www.congress.gov/111/crpt/ srpt338/CRPT-111srpt338.pdf

4 ibid.

5 D Kaufmann and Pedro C. Vicente (n 2) 5-7.

6 See S. Igbinedion, "Workability of the Norms of Transparency and Accountability Against Corruption in Nigeria" (2014) 3 (1) Afe Babalola University Journal of Sustainable Development Law and Policy 150-152; Y. Akinseye-George, Legal System, Corruption and Governance in Nigeria(New Century Law Publishers Ltd. Lagos 2000) 9. 
from morality, ethics, tradition, law, civic virtues and normal duties for private pecuniary or status gains. The common denominator in all these is that corruption is the abuse of office, abuse of due process for personal or selfish interest as against the common good. It is usually preceded by financial or non-financial inducement.

Corruption has pervaded all spheres of the Nigerian life from the mundane to the sublime. ${ }^{7}$ It has become systemic and a way of life of many public servants. In Nigeria, corruption has increasingly become a central issue in election campaigns and military interventions in the polity. ${ }^{8}$ The corruption phenomenon has the concomitant effect of exacerbating poverty and has been held responsible for underdevelopment, increase in the cost of goods and services, the production of substandard goods and services as well as the systemic destruction of the society. Corruption makes the cost of doing business extremely high. ${ }^{9}$ According to a former Secretary-General of the United Nations, Mr Kofi Anan, corruption:

is an insidious scourge that impoverishes many countries and affects all. It discourages foreign investments and hinders economic growth. It is a major obstacle to political stability and to successful social and economic development of any nation. ${ }^{10}$

7 S. Igbinedion (n 6); N Ikpeze, "Fusion of Anti-Corruption Agencies in Nigeria: A Critical Appraisal" (2013) 1 (1) Afe Babalola University Journal of Sustainable Development Law and Policy 148-150; Gresham Sykes \& David Matza, cited in Obi N. I. Ebbe, "Political Corruption in Africa," in Rick Sarre, et al (eds), Policing Corruption: International Perspectives (Lexington Books 2005) 105.

8 For example, from 1996 to 2005, the Corruption Perception Index (CPI) of the Transparency International (TI) ranked Nigeria in the category of the six most corrupt countries in the world. See generally Transparency International, Corruption Perception Index accessed 28 August 2017. See also N Goodling, "Nigeria's Crisis of Corruption: Can the UN Global Programme Hope to resolve this Dilemma?" (May 2003) 36 Vanderbilt Journal of Transnational Law 997, 1003.

9 Paolo Mauro, "The Effects of Corruption on Growth, Investment, and Government Expenditure: A Cross-Country Analysis," in Kimberly Ann Elliot (Editor), Corruption and the Global Economy (Institute for International Economics 1997) 90-91 (suggesting an inverse relationship between corruption and investment); Syed Hussein Alatas, Corruption: Its Nature, Causes and Functions (Gower Publishing Company Limited 1990) 10-16; J Mbaku (ed), Corruption and the Crisis of Institutional Reforms in Africa (The Edwin Mellen Press 1998) 54-55.

10 United Nations Office on Drugs and Crime, Global Action against Corruption; The Merida Papers (Vienna United Nations, 20014) 1-2. 
Nigeria'sunder-development, despite the abundance of human and material resources, is because of the corruption that has pervaded the firmament of governance for many decades. Indeed, a Prime Minister of Britain recently described Nigeria as a "fantastically corrupt" country. It is in the light of this that the government has decided to fight headlong this hydra-headed and insidious corruption scourge. It is a general opinion in Nigeria that if the government is serious about this fight against corruption, then, no official should be immune from prosecution for corrupt practices.

Immunity has several meanings depending on the context of its use. In legal parlance, immunity refers to exemption from performing duties, which the law generally requires other citizens to perform, or from a penalty or burden that the law generally places on other citizens. According to Black's Law Dictionary, the term immunity means an exemption from a duty, liability, or service of process, especially such as exemption granted to a public official. ${ }^{11}$ The Dictionary further defines immunity by classifying it as absolute, congressional, constitutional, diplomatic, discretional, etc. ${ }^{12}$

Section 308 of the 1999 Constitution of the Federal Republic of Nigeria (as amended), popularly called the Immunity Clause, confers immunity from legal proceedings on certain political office holders. ${ }^{13}$ Political office holders so protected include a person holding the office of President or Vice-President, and Governor or Deputy Governor. The origin of this class of immunity dates back to the era of absolute monarchs, when it was believed that a king could do no wrong; hence the term "Sovereign Immunity". ${ }^{14}$ The purpose of the immunity clause is to provide the incumbent a free hand and mind to perform the duties and responsibilities of his office without distraction from litigation. This, however, does not prevent criminal investigation while in office. The immunity is essentially for the protection of the dignity of the office and not for the individual office holder as such. If a civil or criminal proceeding was instituted against any person before he/she became

11 Black's Law Dictionary, 8th Edition (Thoins on West-USA, 2004) Pg.1438; Oxford Dictionary of Law, 6th Edition (Oxford University Press) 265 merely defines immunity as freedom or exemption from legal proceedings.

12 ibid.

131999 Constitution of the Federal Republic of Nigeria C 23 LFN 2004.

14 It is provided for in s267 of the 1979 Constitution and S161 of the 1963 Constitution. 
President, Vice-President, Governor or Deputy Governor, the action will abate automatically.

Many scholars and commentators have argued that granting some categories of public office holders immunity from prosecution while the government says it is fighting corruption is ironical. ${ }^{15}$ However, experience has shown that it is not only protected officers that are corrupt in Nigeria. There have been cases of corrupt practices carried out by officials who are not protected by the immunity clause. Examples are local government chairmen, directors of government institutions, ministers, and so on. For example, a Director of the Police Pension Fund embezzled several billions of the Nigerian Naira (local currency) recently. These categories of persons are not protected by section 308 of the Constitution. The incentive for corruption is then is not the immunity clause. Observably, the Nigerian corruption problem is not in the immunity clause butwith a currently unidentified factor.

This article examines the utility or otherwise of the immunity clauses in the fight against corruption in Nigeria. After this introduction, section 2 reviews the scope, extent and limits of constitutional immunity in Nigeria as it relates to the officers protected, the arguments on its' retention in the constitution. Section 3 examines how state practices in other jurisdictions with respect to absolute or restrictive immunity clauses can guide constitutional reform on immunity in corruption cases in Nigeria. Section 4 discusses why it is expedient to retain constitutional immunity clauses in Nigeria, while demonstrating that expanding it to cover the leadership of the National Assembly and States Houses of Assembly should be discountenanced. Section 5 is the conclusion

\section{MEANING AND HISTORICAL EVOLUTION OF IMIMUNITY}

The concept of immunity stemmed from Sovereign or State Immunity, that is, the ability of a state to invoke immunity from the jurisdiction

15 See F. Falana, "Official Corruption and Immunity in Nigeria" Premium Times (7 July 2016); C Speckbacher, Immunities from the Perspective of the CoE's Group of States Against Corruption (GRECO) (2014) 1-3; Transparency International, "When Immunity Becomes a Licence to Break the Law" (29 April 2013) < https:/ /www.transparency.org/news/feature/when_immunity_becomes_a_ licence_to_break_the_law $>$. 
of the courts of another state in circumstances where the courts of that other state would have otherwise been vested with jurisdiction on the subject matter. ${ }^{16}$ Jurisdiction itself concerns the power of the state to affect people, property and circumstances and reflects the basic principles of state sovereignty, equality of states and non-interference in domestic affairs. ${ }^{17}$

Under Customary International Law, a foreign State or Head of State could sue in a foreign court but could not be sued without his consent. ${ }^{18}$ Sovereign Immunity ${ }^{19}$ is, therefore, a doctrine precluding the institution of a suit against the sovereign (government) without its consent. It springs from the English common law concepts that (1) the "King can do no wrong" 20 and (2) that there can be no legal right as against the authority that makes the law on which the rights depends.The basis of this immunity was the equality of Sovereigns who could, therefore, not exercise power over one another - "par in parem non habit imperium". ${ }^{21}$ This privilege is based on reciprocity and comity. It ensures that states and heads of states are unimpeded in the exercise of their functions.

The main incidence of immunity is that the beneficiary is exempted from the jurisdiction of a foreign court. Submission to jurisdiction must be proved; such submission may be by treaty or by contract with a private party. The property of a foreign state, such as a warship ${ }^{22}$ or an embassy is protected by immunity. According to Watts, ${ }^{23}$ Sovereignty, until recently, was regarded as appertaining to a particular individual

16 H.A. Olaniyan, "United Nations Convention on Jurisdictional Immunities of States and Their Property: Why Nigeria Should Ratify and Domesticate It" (2006) 1, Current Law Series 128.

17 Malcolm N. Shaw, International Law (4th ed), Cambridge University Press 1997) 452.

18 U.O. Umozurike, International Law (3rded, Spectrum Books Limited, 2005) 90.

19 This is otherwise called State Immunity and the two can be used interchangeably. The doctrine, though commonly believed to be rooted in English law, is actually rooted in the inherent nature of power and ability of those who hold power to shield themselves.

20 From the olden days, it was believed that kings ruled by divine right and that all rights flowed from the sovereign.

21 That is,"an equal has no power over an equal".

22 For example, Art; 95 of the UN Convention on the Law of the Sea, 1982 provides - "warships on the high seas have complete immunity from the jurisdiction of any state other than the flag state".

23 AD Watts, "The Legal Position in International Law of Foreign Heads of States, Heads of Governments and Foreign Ministers, 247 HR 1994. 
in a state and not as an abstract manifestation of the existence of power of the state. That Sovereignty could not be made subject to the judicial process of his country and could not be sued in a foreign court was gradually extended to state sovereignty. Indeed, the combined effects of the provision of Article 2(1) of the charter of the UN and the maxim par in parem non habet imperium made it virtually difficult for the municipal court of a state to manifest its power over a foreign sovereign state without the latter's consent.

The leading case of the doctrine of Sovereign Immunity is the case of the Schooner Exchange $v$ Mcfaddon ${ }^{24}$ where Chief Justice Marshall of the United States' Supreme Court declared that the jurisdiction of a state within its own territory was exclusive and absolute.

According to Marshall C.J.,

One sovereign, being in no way amenable to another, and being bound by obligations of the highest character to degrade the dignity of his nation ... can be supposed to enter a foreign territory only under an express license, or in the confidence that the immunities belonging to his independent sovereign station,though not expressly stipulated, are reserved by implication, and will be extended to him. ${ }^{25}$

The doctrine was equally discussed in the Parlement Belge Case ${ }^{26}$ where the English Court of Appeal stated that every state:

... declines to exercise by means of its courts any of its territorial jurisdiction over the person of any Sovereign or ambassador of any other state, or over the public property of any state which is destined to public use ... though such sovereign ambassador or property are within its jurisdiction.

In Under Erill $v$ Hermandez, ${ }^{27}$ the court said:

Every sovereign state is bound to respect the independenceof every other Sovereign State and the courts of the countrywill not sit in judgment on the acts of the government ofanother done in its own country.

24 7, Cranch 116 (1812).

25 The Schooner Exchange v. Mcfaddon, 7 Cranch 116 (1812) ep.i.

26 (1880) 5 PD 19).

27168 US 250 (1897). 
Discussed below is the case of Mighell $v$ Sultan of Jahore, which established that the scope of Sovereign Immunity extends to personal acts of the sovereign.

\section{ABSOLUTE VERSUS RESTRICTIVE IMMUNITY}

One of the most controversial aspects of the doctrine of immunity is whether it embraces all state acts or only some of them. When governments restricted themselves purely to governmental functions, it was easier to concede them immunity.

A Head of State travelling abroad is entitled to complete immunity and any building occupied by him is extra-territorial. If he travelled Incognito, his immunity commences as soon as he declares his identity. In Mighell $v$ Sultan of Jahore, ${ }^{28}$ under the assumed name of Albert Baker, the Sultan, while in Britain, contracted to marry Miss Mighell. On failing to do so, she sued for a breach of promise. The Sultan's claim of immunity was upheld on his revealing his true identity.

If there is doubt as to whether an entity deserves immunity, the question is referred to the ministry for External Affairs whose statement is conclusive. In the Arantzazu Mendi Case, ${ }^{29}$ the statement from the British foreign office [that Britain] recognized defacto the government of General Franco conferred immunity on the ship, which was held on the orders of that government, as opposed to the de jureclaim of the Republican Government.Then, if there are two possible sovereigns, the External Affairs Ministry's statement is decisive. ${ }^{30}$

Generally speaking, there is no consistent practice with respect to which organ of a foreign state or subdivision, such as a province or region, should be entitled to immunity. Certain municipal systems grant immunity to political subdivisions while others do not. France denies such immunity, while USA and Britain accord it. Britain recognized the immunity of the Sultan of Jahore but another Magistrate court in Britain rejected the claim made by the Agent-General of Eastern Nigeria not being an agent of the Nigerian Federal Government. ${ }^{31}$ This would appear to be an internal arrangement that is applied without strict uniformity. The European Convention on State Immunity 1972 does not recognize

28 (1894) QB 149.

29 (1939) AC 256.

30 Haile Selassie v. Cable and Wireless Ltd (1939) ch D 182 (1938) ch D 545.

$31 R v$ Achara 1963 (unreported). 
the immunity of political subdivision by providing that contracting states may declare that constituent parts may invoke their provision and bear the corresponding obligations.

Governments in commercial activities led to an increasing number of states distinguishing between purely governmental function - acta jure imperil - and commercial activities acta jure gestonis; - and restricting immunity to the former.

Lord Wilberforce in 1 Congress Del Parside ${ }^{32}$ puts the rationale succinctly:

... it is necessary in the interest of justice for individuals havingtransactions with State to allow them to bring each transactionbefore the courts. To require a state to answer a claim based upon each transaction does not involve a challenge to the governmental act of that State. It is, inaccepted phrases, nether a threat to [the] dignity of that state, nor any interference with its sovereign function ...

This distinction has led to the doctrines of absolute immunity and the doctrine of restrictive immunity. This distinction has been adopted in a number of multilateral treaties. The Paris Peace Treaties of 1919 and 1920 denied the defeated states any right, privileges or immunities in foreign trade. The Brussels Convention for the Unification of Certain Rules Relating to the Immunity of State-Owned Vessels 1926 and the Additional Protocol $1934^{33}$ also made the distinction. The same principle applies to the General Convention of the High Seas 1958, ${ }^{34}$ the Convention on Territorial and Contiguous Zone 1958, ${ }^{35}$ the Convention on the Settlement of Investment Disputes between States and Nationals of the Other States $1965,{ }^{36}$ the Convention on Civil Liability for Oil Pollution Damage $1969^{37}$ and the United Nations Convention on the Law of the Sea $1982 .{ }^{38}$

The European Convention on State Immunity with its Additional Protocol $1972^{39}$ adopts the distinction as does the Convention of

3219813 WCR 329, Fox 98 LQR (1982)94.

33176 LNTS 199.

34450 UNTS, 42.

35506 UNTS, 205.

36575 UNTS, 159.

37973 UNTS, 3.

38 Article 96.

3911 ILM, 470. 
Immunity of States in Respect of Commercial and Other Transactions of a Private Character 1960, ${ }^{40}$ the Convention on Jurisdictional Immunity of States of OAS $1983^{41}$ the Harvard Draft 1932, the German Society of International Law 1968 and the Montreal Draft Convention on State Immunity of the International Law Association 1982. Britain too adopted the distinction in $1978 .{ }^{42}$

Under the doctrine of Absolute Immunity, the Sovereign is immune from foreign jurisdiction in all cases irrespective of the circumstance. However, the flurries of activities of states have led to the modification of the absolute immunity rule. The modification has led to the adoption of the doctrine of restrictive immunity.

In the Parlement Belge case (Supra), the Court of Appeal stressed that the principle to be deduced from all the relevant preceding cases was that every state:

declines to exercise by means of its courts any of its territorialjurisdiction over the person of any Sovereign or ambassador or of any other state,or over the public property of any State which is destined to public use ... even though such Sovereign ambassador or property be within its jurisdiction.

The doctrine was equally applied in the case of Porto Alexandre. ${ }^{43}$ The extension of the doctrine to an agent was established in the case of Krasina $v$ Tass Agency ${ }^{44}$ where the Court of Appeal held that the Agency was a State Organ of the USSR and was thus entitled to immunity from local jurisdiction. ${ }^{45}$ However, in Dralle $v$ Republic of Czchoslovakia, ${ }^{46}$ the Supreme Court of Australia declared that:

In the light of the increased activity of states in the commercialfield, the classic doctrine of absolute immunity had lost its meaning and was no longer a rule in international law. ${ }^{47}$

40 A Slan - African Legal Consultative Committee, Third Session, Columbia, 1960 (Secretariat of the committee), New Delhi, India.

4122 ILM, 292.

42 State Immunity Act 1978.

43 (1920) 30.

44 (1949)2 All ER 274.

45 See Also the Case of Duff Development Co. Ltd v. Kelantan Government(1924) 17AC 797.

46 (1950) 17 ILR 155.

47 See also Alfred Dunhill of London v. Republic of Cuba 15 ILM 1976. 
The doctrine of restrictive immunity was accepted in Nigeria in the case of Trendtex Trading Co. Ltd v Central Bank of Nigeria ${ }^{48}$ where the three judges of the Court of Appeal accepted the validity of the restrictive immunity as being consonant with justice, comity and international practice. The court held that the Central Bank of Nigeria was a governmental department but a "legal" entity of its own right and, therefore, not entitled to jurisdictional immunity. ${ }^{49}$ Several states have reflected the restrictive immunity doctrine in their domestic legislations. ${ }^{50}$

\subsection{An Examination of the UK State Immunity Act 1978}

Although the absolute immunity doctrine remained the orthodox position in England until after 1945, an examination of the case law indicates increasing judicial misgiving. The confirmation of the absolute immunity doctrine in the Parlement Belge ${ }^{51}$ was followed for over 50 years but with increasing reservations. The matter came before the Court of Appeal in The Porto Alexandre case, ${ }^{52}$ which concerned a writ issued against a Portuguese requisitioned vessel for non-payment of salvage charges. A Court of Appeal ${ }^{53}$ upheld the ruling of Hill $\mathrm{J}$ that immunity could be claimed simply on the State Immunity Act 1978, enacted to provide a code as to the circumstances in which immunity might be granted. It came into effect on 22 November 1978 and is not retrospective; it therefore follows that cases will come before the courts where the legislation does not pertain either because the events took place before the operative date ${ }^{54}$ or because the facts come within one of the exceptional situations where the legislation does not apply. ${ }^{55}$ The express purpose of the legislation was to enable the United

481 (1977) QB 529 C.A.

49 Several other cases have reaffirmed this decision. See for example, 1 Congresso del Parfido (1981)2 All ER.

50 See for example, the United States Foreign Sovereign Immunities Act 1976, the South African Foreign States Immunities Act 1981 and the United Kingdom Immunity Act, 1978.

51 (1880)5 PD 197.

52 (1920) 30.

53 The Porto Alexandre (1920) 30.

54 D. Bowett (1978) 193; R White (1979) 42 MLR 72; FA Mann (1979)50 BYIL 43; G. Delaume (1979) 73 AJIL 188.

55 Hispano Americana Mercantile SA v. Central Bank of Nigeria (1979)2 Lloyd's Rep. 277; 1 Congresso del. Partide (1981)1 AC 244. 
Kingdom to ratify both the 1926 Brussels Convention on the Unification of Certain Rules relating State-Owned Vessels and the 1972 European Convention on State Immunity. ${ }^{56}$

It is arguable that the legislation would be sufficient to meet the United Kingdom's obligations under the draft of the International Law Commission, should that document one day enter into force. Another important objective was to ensure that the United Kingdom as a centre of trade was not damaged by rules that were thought to be unfavourable to trading interests. ${ }^{57}$

The legislation begins with the general principle ${ }^{58}$ that a state will be immune from the jurisdiction of the courts of the United Kingdom save in respect of exceptional situations listed in Sections 2-11. Section 2 of the legislation provides that a state shall not have immunity if it submits to the jurisdiction after the dispute giving rise to the proceedings has arisen or where there is a prior written agreement. ${ }^{59}$ The effect of this provision is to set aside the old common law rule that a state could not agree to submit to the jurisdiction in advance. ${ }^{60}$ Thus, Saville $\mathrm{J}$ was able to rule in A Company Ltd $v$. Republic of $X^{61}$ that a written submission in advance could on its construction extend to both process and to pre-judgment attachment.

However, a choice of law clause in favour of the law of the United Kingdom does not constitute a submission. ${ }^{62}$ Section 2(3)(a) provides that a state is deemed to have submitted if it has instituted the proceedings, and normally admission will arise if the state has

56 The European Convention on State Immunity was signed in Basle by seven countries including the United Kingdom on 16 May 1972 and came into force on 11 June 1976.

57 See also, Arbitration Act 1979. This concern was mentioned several times during the parliamentary debates and was precipitated by fears that the United States Foreign Sovereign Immunities Act 1976 could lead to financial transactions being lost by the city of London.

58 State Immunity Act 1978, sl; Art 15 of the European Convention on State Immunity (1972).

59 See also, Art 1 and 2 of the European Convention on State Immunity (1972).

60 Kahum v. Pakistan Federation (1951)2 KB 1003; Baccus SRL, v. Servicio Nacional del Trigo (1957) 1 QB 438.

61 A Company Ltd. v. Republic of X (1900)2 Lloyd's Rep 520 (although by operation of s 16 of the Act property subject to the Diplomatic Privileges Act 1964 will be immune).

62 State Immunity Act 1978, s. 2(2). 
intervened in or taken any steps in the proceedings. ${ }^{63}$ However, there will be no submission if the purpose of intervening is to assert immunity ${ }^{64}$ or to claim an interest in property in circumstances where the state would have been able to waiver. Then, there must be clear evidence of an intention to waive so that a written letter to an employee indicating that she might have certain right under United Kingdom employment could not be construed as being capable of creating a prior written agreement under s. $2 .{ }^{65}$

Similarly as a matter of construction, a letter sent by a medical officer to an industrial tribunal did not constitute submission to the jurisdiction. ${ }^{66}$ Any submission will be deemed to extend to any appeal arising out of the action but not to any counterclaim unless it arises out of the same legal relationship or facts as the claim. ${ }^{67}$ Any submission to the jurisdiction must be by a person having the capacity to act, such as the head of diplomatic mission or by an authorized agent. ${ }^{68}$ Any question on possible immunity should in principle be decided at the outset of the hearing before the court at first instance examines the merits of the case. ${ }^{69}$

It would seem that if a tribunal at first instance fails to consider the question of immunity because of the absence of relevant evidence then the appellate body is under a duty to consider the matter and is not precluded by rules restricting the submission of new evidence on appeal. $^{70}$

\subsubsection{Commercial Transaction ${ }^{71}$}

It is arguable that the most important provision of the legislation is s3, which provides that a state will not be immune in respect of "a

63 State Immunity Act 1978, s.2(3)(b) s.2(3)(b); High Commissioner for India $v$. Ghosh (1960)1 QB 134, 28 ILR, 150.

64 ibid.s 2(4)(a).

65 ibid. s 2(4)(b). This would in principle cover the situation in Compania Naviera Vascongada v. Steamship Cristina (1938) AC 483.

66 Ahmed v. Government of Saudi Arabia (1996)2 All ER 248.

67 Arab Republic of Egypt v. Camal-Ehlin (1996)2 All ER 237.

68 State Immunity Act 1978, s.2(6) reflecting to some extend the position at common law, see Sultan of Johore v. Abubakar Tunka Aris Benduhor (1932), AC 318, High Commissioner for India v. Cheshj (1960)1 QB 134. 28 ILR 150 (CA).

69 State Immunity Act 1978, s.2(7).

70 United Arab Emirates v. Abedghafor (1993) ICR65; Arab Republic of Egypt $v$. Gamal Eldin (1996)2 All ER 237.

71 European Convention on State Immunity (1972), Art 4. 
commercial transaction" or; ... an obligation of the State which by virtue of a contract (whether a commercial transaction or not) fails to be performed wholly or partly in the United Kingdom. In these circumstances the definition of a "commercial transaction" is central and this is provided by $\mathrm{s} 3(3)$ which defines a commercial transaction as:

(a) any contract for the supply of goods and services;

(b) Any loan or other transaction for the provision of finance and any guarantee or indemnity in respect of any such transaction or of any other financial obligation; and

(c) Any other transaction or activity (whether of a commercial, industrial, financial professional or other similar character) into which a state enters or in which it engages otherwise than in the exercise of sovereign authority.

It is clear that the draftsman has chosen to avoid the distinction between acts jure imperil and acts jure gestionis. It is also evident that matters falling within s.3 (3) (a) or s3 (3) (b) are automatically commercial transactions while for the purposes of s3 (3) (c) they must be "otherwise than in the exercise of sovereign authority". In respect of this latter expression Evan J., in Australia and New Zealand Banking Group v. Commonwealth of Australia, ${ }^{72}$ held that in interpreting s.3(3)(c) it was important to pay regard to the overall context and that a claim for negligent misstatement arising out of a loan transaction might be caught by both s.3(3)(b) and s.3(3)(c).

Secondly, in respect of s.3(1)(b) it would seem that in contrast to s.3(1) (a) the contract need not have been entered into by the state itself and the formulation is wide enough to include contracts of indemnity and guarantee. ${ }^{73}$ One of the difficulties in this context will be whether an analysis of conduct is to be subject to minute dissection or is one entitled to take a broad view of what constitutes "sovereign activity". Although the case did not concern commercial dealings this division of opinion is to be found in the speeches in Kuwait Airways Corporation v. Iraqi Airways Company; ${ }^{74}$ this latter case indicates that

72 Australia and New Zealand Banking Group v. Commonwealth of Australia (1989) (see transcript).

73 Macline Wastson and Co Ltd. v. Department of Trade and Industry (1987) Ch. 72.

74 (1993) 1 WLR 1147. 
conduct has to be analysed in detail over time so that subsequent conduct with third parties may deprive the transaction of the protection of "sovereign activity".

While it is clear that a United Kingdom judge will simply follow the words of the State Immunity Act 1978 some guidance can be obtained by observing the practice in the United States where the restrictive approach was adopted much earlier. The relevant United States legislation defines a "commercial activity" as "a regular court of commercial conduct or a particular commercial transaction or act". The approach of the United States courts has been to focus upon the nature rather than the purpose of the act and they have not been slow to find that an activity is in substance, commercial. Thus, attempts to engage in price fixing by states ${ }^{75}$ or the operation of an insurance monopoly ${ }^{76}$ will constitute commercial activities as will the issuing of commercial bonds. ${ }^{77}$ In like terms, the conduct of a state airline ${ }^{78}$ or the purchase of cement ${ }^{79}$ will be regarded as commercial activities as indeed will the issuing of foreign treasury notes. ${ }^{80}$

Particular difficulty has been encountered in the United States in respect of the activities of state-controlled or state-owned banks. In such cases, a distinction has emerged between those cases where the state bank acts as an internal regulator in which the act of state doctrine may produce jurisdiction ${ }^{81}$ and those instances where the state bank is engaged in normal operations within capital markets; in the latter instance the activity will be regarded as commercial and not subject to immunity. ${ }^{82}$

Although the United States has followed the restrictive doctrine since 1952 the relevant law is now set out in 1605(a)(2) of the Foreign Sovereign Immunities Act 1976 which provides that the foreign state will not be immune in any situation in which the action is based upon

75 International Association of Muchinists and Aerospace workers v. OPEC (1979) 477 F. supp. 533, (1962) 76 AJIL 160.

76 American International group Inc. v. Islamic Republic of Iran (1981) 75 AJIL 371.

77 Carl Marks \& Co. v. Union of soviet Socialist Republic (1988)82 AJIL 129.

78 Argentine Airline v. Ross (1974) 63 ILR 198.

79 National American Corporation v. Federal Republic of Nigeria (1977)16 ILM 505; (1978) 17 ILM 1407.

80 Schmult v. Polish People's Republic (1984) 742 F 2d 67.

81 Callejo v. Buncomer SA (1985) 24 ILM 1050.

82 Alfred Dunbill of London Inc v. Republic of Chuba (1976) 425 US 682; 66 ILR 212; Republic of Argentina v. Wedlocer Inc. (1992) 100 ILR. 309. 
a commercial activity carried on in the United States by the foreign state; or upon an act performed in the United States in connection with a commercial activity of the foreign state elsewhere or upon an act outside the territory of the United States in connection with a commercial activity of the foreign state elsewhere and that act causes a direct effect in the United States'.

The sub-section embraces three elements. In respect of the first element it is clear that the commercial activity taking place in the United States must be substantial and not de minimis. ${ }^{83}$ Where the act performed in the United States is in connection with a commercial activity of a foreign state elsewhere then the act within the United States must be sufficient to constitute the foundation of a legal claim. ${ }^{84}$ In respect of the third element, namely, that of direct effect, something of legal significance must take place within the United States. ${ }^{85}$

\subsubsection{Contracts of Employment ${ }^{86}$}

Section 4 of the State Immunity Act 1978 makes specific provision in respect of contracts of employment which were specifically excluded from s.3. ${ }^{87}$ Section 4 provides that there will be no immunity in respect of contracts of employment where the contract is made in the United Kingdom or the work was to be wholly or partly performed there. ${ }^{88}$ However, the section excludes those cases where, when the proceedings are brought, the individual is a national of the state concerned ${ }^{89}$ or

83 Zahun v. Kingdom of Saudi Arabia (1988)82, AJIL 828, 849 F 2d 1511 (US Court of Appeals).

84 Zahun v. Kingdom of Saudi Arabia (1988)49 F 2d 1511: Saudi Arabia v. Nelson (1993) 100 ILR 545.

85 Trans American Steamship Corporation v. Saudi Democratic Republic (1986) 76 AJIL 357; 767 F 2d 998;Texas Trading \& Milling Corporation v. Federal Republic of Nigeria (1981) 20 ILM 620; 647 F 2d 300; 63 ILR 552; Zolanv. Kingdom of Saudi Arabia (1988) 849 F 2d 1511; but see also Republic of Argentina v. Welbover Inc. (1992) 100 ILR 509.

86 Art 5, European Convention on State Immunity (1972); see H. Fox, Employment Contracts As an Exception to State Immunity Is All Public Service Immune" (1995) 55 BYIL 97, R. Carnett, State immunity in employment matters' (1997) 46 ICLQ 81.

87 State Immunity Act 1978, s.3(3)(c).

88 ibid, s.4(1).

89 As was the case in Arab Republic of Egypt v. Gamal Eldin (1990)2 All ER 237. This would have been the case in Songupta v. Republic of India (1983) ICR 221 had it not been outside the legislation because the employee had been appointed price to the commencement date. State Immunity Act 1978, s. 42(2)(a). 
where the individual was neither a national of the United Kingdom nor habitually resident ${ }^{90}$ there, or where the parties have reached an agreement in writing to the contrary. ${ }^{91}$ However, the exclusions in respect of contracts of employment have to be read with s.16(1), which removes the application of the provisions in respect of members of a diplomatic mission or consular staff. ${ }^{92}$

\subsection{Immunity Clause in the United States of America}

Unlike the case in Nigeria's Constitution, the immunity clause is not enshrined in the Constitution of the United States of America. Notably, as a common law principle, the courts have recognized certain types of executive immunity. ${ }^{93}$ The President has absolute immunity from civil liability for his official acts. The leading case on this is Nixon $v$. Fitzgerald. ${ }^{94}$ In November 1968, Ernest Fitzgerald, an air force management analyst testified before congressional sub-committee that aerospace developmental projects would necessitate an increase in cost of over US\$2 billion. In January 1970, the Pentagon fired him in a cost-saving re-organization.

Fitzgerald, who believed he was fired from his defence department job in retaliation for testimony in which he had criticized military cost overruns, sued President Nixon and some of his administrative officials for violating his First Amendment and Statutory Rights.

The United States Supreme Court in its lead judgment read by Justice Powel held that the President is entitled to absolute immunity from civil damage actions for all acts within the "outer perimeter" of his authority. The Court held that since the President has authority to prescribe the manner in which the business of the Armed Forces will be performed, including the authority to dismiss personnel, Nixon was immune from liability for firing Fitzgerald even if he caused it maliciously or in an illegal manner.

90 State Immunity Act 1978, s.42(2) (b) for recent consideration of the expression "habitually resident", see Nesa v. Chief Adjudication Officer (1998)2 AB ER 778 (CA) (1999) 1 WLR (HL) for a review of the concept, are P. Ragerson, Habitual residence the new domicile (2000) 49 ICLQ 86.

91 State Immunity Act 1978, s.4((1)(c).

92 Ahmed v. Government of the Kingdom of Saudi Arabia (1996)2 All ER 248.

93 S.L. Emmanuel, Constitutional Law (Larchmont N.Y. Emmanuel Publishing Corp., 1992)p.

94457 U.S. 31 (1982). 
However, the President does not have immunity at all for acts that are completely unconnected with his official duties. In Clinton $v$. Jones, ${ }^{95}$ Paula Jones brought a suit for private damages against President Bill Clinton while he was in office. Jones claimed that while she was by the State of Arkansas and Clinton was Governor of Arkansas, he made sexual advances to her. Clinton contended that as President of the United States of America, he should have temporary immunity to last while he is in office against virtually all civil litigations arising out of events that occurred before he took office.The court, unanimously rejecting the contention, held that no immunity of any kind is expressed in the constitution and that by the decision in the Fitzgerald case, unofficial acts such as the one this case was based on are not within the perimeter, not even the outer perimeter of the President's official responsibility.

The American President is also not immune from court processes. The President could be subpoenaedto produce relevant documents in criminal matters. In United States v Nixon, ${ }^{96}$ in March 1974, a federal grand jury indicted seven Nixon aides on charges of conspiracy to obstruct justice and other Watergate-related offences. The President was named as an un-indicted co-conspirator. The Watergate Special Prosecutor then persuaded the federal trial court to issue a subpoena duces tecum to the President requiring him to produce various tapes and documents relating to certain meetings involving the President. These documents and tapes were to be used during the trial of the indictments. The President released some of the tapes but refused to produce the tapes themselves and moved to quash the subpoena. The trial court rejected the President's claim of privilege.

On appeal, it was held that the President is amenable to a subpoena to produce evidence for use in a criminal case despite the general immunity. The court noted that neither the doctrine of separation of powers nor the need for confidentiality of high-level communications without more, could sustain an absolute, unqualified presidential privilege of immunity from judicial process under all circumstances.

From the exposition above, the United States of America practices qualified executive immunity. The President is only immune from civil liability for acts done in the discharge of his official duties.

95165 U.S. L.W. 4372 (27 May 1997). 96418 U.S. 683 (1974). 


\subsection{Immunity Clause under the Nigerian Law}

The 1999 Constitution of the Federal Republic of Nigeria is the supreme law of the land and, by virtue of section 1 of the Constitution, has a binding force on all authorities and persons throughout the federation. Section 308 provides for Restriction on Legal Proceedings as follows:

(1) Notwithstanding anything to the contrary in this Constitution, but subject to subsection (2) of this section.

(a) No civil or criminal proceedings shall be instituted or continued against a person to whom this section applies during his period of office:

(b) A person to whom this section applies shall not be arrested or imprisoned during that period either on pursuance of the process of any court or otherwise; and

(c) No process of any court requiring or compelling the appearance of a person to whom this section applies, shall be applied for or issued:

Provided that in ascertaining whether any period of limitation has expired for the purposes of any proceedings against a person to whom this section applies, no account shall be taken of his period of office.

(2) The provisions of subsection (1) of this section shall not apply to civil proceedings against a person to whom this section applies in his official capacity or to civil or criminal proceedings in which a person is only a nominal party.

(3) This section applies to a person holding the office of President or Vice-President, Governor or Deputy Governor; and the reference in this section to "period of office" is a reference to the period during which the person holding such office is required to perform the functions of the office.The person holding the office does not even have the right to waive the immunity because any such waiver is ineffective as the immunity is not that of the person holding the office but of that particular office he represents during the tenure of the office. ${ }^{97}$

97 Alamieyesigha v.Yeiwa (2001)33 WRN 144. 
For example, in Tinubu v. IMB Securities Plc, ${ }^{98}$ the Court of Appeal took the view that a person to whom section 308 applies could not even as an appellant pursue an appeal before this Court during the period of his office. The court took the view that a plaintiff to whom section 308 did not directly apply could not initiate or continue proceedings against a person to whom section 308 applies. The latter person could not pursue an appeal against any decision of the trial court. The reason being that, to allow that person was akin to a continuation of the proceedings before the lower court, the Supreme Court in upholding the reasoning of Court of Appeal said per Iguh JSC.

In my view, the Immunity granted to the incumbent of the relevant office under section 308 (1) (a) of the Constitution prescribes an absolute prohibition on the courts from entertaining any proceedings, civil or criminal, in respect of any claim or relief against a person to whom that section of the Constitution applies during the period he holds office. No question of waiver of the relevant immunity by the incumbent of the office concerned or indeed, by the courts may therefore arise. In my view, the Court of Appeal declined to entertain the appellant's appeal pending before it as to do otherwise would amount to continuing the plaintiff/ respondent's suit against the defendant/appellant, a suit which under section 308 (1) (a) of the 1999 Constitution shall not be continued against the appellant while he remained Governor of Lagos State. ${ }^{99}$

Similarly, in Industrial Commercial Service Ltd v. Balton B. V., ${ }^{100}$ the Court of Appeal held that no question of waiver of the relevant immunity by the incumbent of the offices concerned, or indeed by the courts may arise; it is an absolute bar. Even where the incumbent fails to rely on the immunity clause the court will still decline jurisdiction to entertain the case. In Rotimi and others $v$. Macgregor, ${ }^{101}$ an action for damages for trespass committed by the defendants against the plaintiff was brought before the court. While the action was pending the first

981 (2001) 16 NWLR (Pt 740) 670.

99 ibid 695.

100 (2003) 8 NWLR (Pt 822) 223. See also Akume v. National Party of Nigeria (1984)5 NCLR 494, where the court rejected the contention of the plaintiff counsel that Governor AperAku could easily waive the immunity and subject himself to trial.

101 (1974) NSCC 542. 
defendant became the Military Governor of Western State. The provision of section 161(1)(c) of the 1963 Constitution applied and the action should have been struck out against him. The Supreme Court held that section 161(1)(c) of the Constitution prescribesimmunity from court process, and the incumbent of the relevant office cannot waive the effect of the section, so that even if it was not relied on before the court, the court is bound to give effect to it.

The immunity clause has been criticized on the ground that the public officials mentioned in section 308(3) of the Constitution are incentivized in the commission of civil wrongs or crime. For instance, by the provision of the immunity clause, it is almost impossible to hold any case against an incumbent, even if he openly commits an offence. Hence, the Governor of a State is practically above the law because he is immune to prosecution for any type of offence while his tenure lasts. That is why some Governors were alleged to have indulged in carefree looting of their state treasury. Some Governors have allegedly been involved in the murder of political opponents while some have been arrested abroad for money laundering and other criminal activities.Also, waiting for four or eight years before commencing civil or criminal proceedings against the President, Vice-President, Governor or Deputy Governor, will create an opportunity for a criminally-minded executive to destroy the evidence and make it almost impossible for the law to take its due course. ${ }^{102}$ However, there are some exceptions to the immunity clause, these include:

a. Where the incumbent is a nominal party in a suit and suits against official acts:

The 1999 Constitution stipulates that the immunity clause does not extend to a civil action against the President, Vice-President, Governor or Deputy Governor in his official capacity, as well as a civil or criminal action in which he is only a nominal party. ${ }^{103}$ It simply means that immunity granted by section 308 does not protect official acts. So, an incumbent cannot while acting in his official capacity claim immunity from legal process. The section will only protect acts as done in the personal capacity and while the person is in office at the time the writ was issued. For

102 This Day, 22 February 2008, p.80.

103 S. 308 (2)1999 Constitution. 
example, in Abacha v. Fawehinmi, ${ }^{104}$ the Supreme Court held per Uwaifo JSC.

Subsection (2) is self-explanatory. The immunity provided for does not apply to [the] person in question in his official capacity or to a civil or criminal proceeding in which such a person is only a nominal party. The immunity is to protect such a person from the harassment, the immunity provided for in the Constitution does not arise and does not apply.

Where the incumbent is only a nominal party in the civil suit, the immunity granted by section 308 of the Constitution will not apply. In Anzaku v. Governor of Nasarawa State, ${ }^{105}$ an action for wrongful dismissal from employment by Lafia Local Government Council was successfully maintained against the Lafia Local Government Council with the Governor as a nominal party. ${ }^{106}$

b. Police investigations - Section 308 of the 1999 Constitution does not immune the officials stipulated in its subsection (3) from police investigation.

This is because investigation of a crime by the police is a preliminary course, which may or may not result in a criminal prosecution. There is a distinction between "proceedings" and "investigation" leading to the proceedings. In civil proceedings investigation is hardly necessary, but in criminal proceedings, where allegations of crime are made, there is always the need to ensure that there is sufficient evidence to prosecute and these may involve questioning, arrest or even detention where necessary of the person or persons involved. There is no doubt that in all criminal allegations, investigation plays an important part and it will make or mar subsequent criminal proceedings, but that does not qualify it as being part and parcel of the proceedings.

It follows, therefore, that police investigation of a criminal allegation is not and cannot be regarded as criminal proceedings so as to qualify such proceedings under section

104 (2000)6 NWLR (Pt. 660) 288. See also Dasuki v. Muazu (2002)16 NWLR (Pt. 793) 319.

105 (2005) 5 NWLR (Pt. 919). 448. See also ICS (Nig) Ltd v.Balton B.C. (2002)8NWLR (Pt. 822) 223.

106 ibid 351-532. 
308(1). The holders of office mentioned in section 308(3) can, therefore, be investigated provided they are not questioned, arrested or detained or asked to make any statement in connection with such investigation. ${ }^{107}$ It is important to note that when an incumbent is investigated and strong evidence is gathered against him, it will not be used to commence criminal proceedings against him. The evidence must be kept in the cooler until such a time the officer vacates the office.

c. Election petitions - The immunity granted certain functionaries of government from civil and criminal proceedings under section 308 of the 1999 Constitution does not extend to election petition proceedings. This is because election petitions are special proceedings completely divorced and separated from civil proceedings within the context of section 308 .

d. Acts Done Outside Nigeria - The immunity granted certain officials under section 308 of the 1999 Constitution does not cover acts done by these officials outside the country. This was why the former Governor of Bayelsa State (Governor Alamieyeseigha) was arrested in Britain while he was still the Governor of Bayelsa State for money laundering. A discussion of the case will now be carried out.

\subsection{Immunity Clause and Acts Done Outside Nigeria: The Alamieyeseigha Case}

In September 2005, the late Diepreye Solomon Alamieyeseigha, the then Governor of Bayelsa State, one of the 36 constituent states that make up the Federal Republic of Nigeria, was arrested, detained and charged with the criminal offence of money laundering. The governor challenged his arrest, detention and subsequent arraignment in court on the grounds that as the governor and chief executive of Bayelsa State, he enjoyed Sovereign Immunity in International Law.Following this claim, several jurists, professors of law, senior advocates in the profession and other public affairs commentators have taken positions on the issue raised.

Professor Fidelis Oditah, QC, a counsel to the governor was of the

107 Fawehinmi v. Inspector General of Police 10 NSCQR 826. 
opinion that the governor was entitled to immunity in Britain. ${ }^{108} \mathrm{He}$ believed that "[L]ike the Federal Government, Bayelsa State has three arms of government - the executive, legislature and judiciary. Accordingly, as the Head of Bayelsa State, the governor has immunity from criminal jurisdiction under all applicable laws including the laws of Nigeria, England and International Law...".

Chief Gani Fawehinmi, SAN, a foremost Nigerian legal practitioner opined that no immunity would avail the embattled governor. According to him, "Under International Law, immunity is enjoyed by the head of a Sovereign State. State here means nation state and not a geographical or political division within the nation state like Bayelsa State. The Customary International law recognizes nation division within a nation state as deserving immunity for the head of that nation state. In Nigeria, the head of the nation was President Olusegun Obasanjo. According to the political division in Nigeria, there were 36 geographical states with 36 governors but none of them is the head of the nation state of Nigeria. None of the 36 governors enjoys immunity under the Customary International law, consequently, the Bayelsa state governor; Chief Diepreye Alamieyeseigha does not enjoy immunity outside Nigeria. ${ }^{109}$

Dr Olu Onagoruwa, a former Attorney-General and Minister of Justice of the Federation of Nigeria interjected that the governor was a diplomatic agent of Nigeria and thus cannot be tried or arrested for any criminal offence. He believed that "by all account, Alamieyeseigha is a high diplomatic agent of the Nigerian state. He presides over the executive apparatus of his state, which is part of the Nigerian state ...." as an agent of the Nigerian state, Alamieyeseigha cannot be arrested or detained". ${ }^{110}$ He concluded by saying that the governor's trial is a breach of international law.

Professor Ijalaye, an emeritus professor of law at the Obafemi Awolowo University, Ile-Ife, held an opinion that coincided with Fawehinmi. On the immunity conferred on any governor of the 36

108 See "Alamieyeseigha's Detention and Arraignment Violate International Law"The Guardian Newspaper (4 October 2005) 69.

109 See the Punch Newspaper, 4 October 2005, 46

110 See "Alamieyeseigha and International Law"The Guardian Newspaper (3 October 2005) 65. This argument appears to me to be quite sound. It would appear that a better immunity would have been available under diplomatic immunity than sovereign immunity. The learned former Attorney cited decided case like US $v$ Telum the case of the Dutch Ambassador and the LandaraveHessee case of 1963; Mighell v. Sultan of Jahore amongst others to buttress this position. 
states of the federation of Nigeria as provided for in Section 308 of Nigeria's Constitution, he believed that sovereignty belonged to the Head of President of a nation-state. He further declared, “.... Foreign heads of state, whether monarchs or presidents, embody in their persons the Sovereignty of their states and when they visit or pass through the territory of another Sovereign and Independent Country, they are wholly exempted from the local jurisdiction, both civil and criminal". ${ }^{111}$ He concluded that no sovereign immunity would avail DSP Alamieyeseigha.

Chief Wole Olanipekun, SAN, a former President of the Nigerian Bar Association (NBA) held the view that the governor enjoys immunity like the president of the Federal Republic. He maintained that Bayelsa State, a political sub-division like any other state, is recognized under International law as a Sovereign state that is entitled to immunity ... that considering both the Nigerian Constitution and the applicable Acts in the UK together with the Vienna Convention and a host of decided cases by British and other foreign courts, that governor DSP Alamieyeseigha enjoys immunity from prosecution in the United Kingdom". ${ }^{112}$

Professor Akindele Oyebode, a foremost jurist and acclaimed Professor of International Law, holds the view that the concept of absolute Sovereign Immunity is otiose, unfashionable in contemporary international law. He believes that at best, what we have is restrictive sovereign immunity and that the immunity, as canvassed by the Governor, cannot avail him. ${ }^{113}$

Professor Itse Sagay, also a Professor of International Law, contends that the Governor enjoys immunity outside Nigeria. He draws the basis of his argument from section 308 of the Nigerian Constitution and declares that:

[T] here can be no basis for concluding that whilst thePresident enjoys sovereign immunity "in that capacity". Governor

111 "Sovereign Immunity and Governor DSP Alamieyeseigha", Guardian Newspaper (11 October 2005) 67.

112 "Alamieyeseigh's immunity under the Nigerian Constitution and International Law", Guardian Newspaper (31 October 2005) 19.

113 This view was expressed on the network service of the Nigeria Television Authority (NTA) on "periscope", a programme that equally featured Professor ItseSagay. The two learned professors took positions that were dramatically opposing. 
Alamieyeseigha, who is protected by identical provisions in the same section as head of the Government of Bayelsa State enjoys some measures of immunity in that capacity.

He further asserts that:

a federation's sovereignty is split between the federal state and the federating states ... that Sovereignty must be divided between the federal state on the one hand, andon the other hand, the member states. ${ }^{114}$

The debate on whether Chief DSP Alamieyeseigha enjoys Sovereign Immunity under International Law continued with learned jurists taking opposing positions. The controversy was so intense and the divergence of opinion so plethora that the whole legal firmament was pervaded by confusion. The British Court's judgment in the case will now be appraised.

\subsection{The Crown Court's Judgment in Alamieyeseigha v. Crown Prosecution Service}

\subsubsection{The charges}

The claimant has been charged by the Crown Prosecution Service ("CPS") with three offences as follows:

In the first charge, the claimant is alleged to have received $£ 420,000$ into a bank account held at HSBC in London on or about the 14 December 2001 contrary to section 93C(1)(A) of the Criminal Justice Act 1988 as amended. The money, it is alleged, represented the proceeds of a corrupt payment received from an oil and property merchant in Nigeria.

In the second charge, the claimant is alleged to have money laundered the sum of $£ 475,724$ contrary to section 93C(1)(A) of the Criminal Justice Act 1988 as amended by paying into the account of a firm of solicitors (Nedd \& Co) on or about the 22 March 2003, for use when purchasing a property at 68-70 Regents Park Road, London, N3.

The third charge relates to a cash sum of $£ 920,000$, which was found at the claimant's home on 15 September 2005. Again

114 "International Law, Governor Alamieyeseigha and Sovereign Immunity" Vanguard Newspaper(14 October 2005) 19. 
the CPS alleges that this sum represents the proceeds of criminal conduct contrary to section 327(1) of the Proceeds of Crime Act 2002.

\subsubsection{The issue before the British Court ("the Court")}

Whether a Governor and Chief Executive of a state, which is constituent part of the Federal Republic of Nigeria, is entitled to immunity in criminal proceedings brought in the court. Mr Edward Fitzgerald QC, one of the counsels to Diepreye Solomon Peter Alamieyeseigha ("the claimant") had brought a claim by judicial review to quash the decision to prosecute the claimant on the grounds that he is entitled to sovereign immunity in his capacity as Governor and Chief Executive of Bayelsa State, which is a constituent part of the Federal Republic of Nigeria.

\subsubsection{The judgment}

In its decision, the court states that Bayelsa State is not entitled to State Immunity and that the claimant is also not so entitled. In reaching its decision, it took into consideration reports of experts from both the claimant and the defendant.The claimant relied on a report of Professor Benjamin Nwabueze, a highly experienced Nigerian advocate as well as a writer on legal matters. The defendants adduced a report from $\mathrm{Dr}$ Tunde Ogowewo, a Senior Lecturer at King's College, London, who is an expert in Nigerian Law. They both explained the relevant provisions in the Constitution of the Federal Republic of Nigeria 1999 ("the Nigerian Constitution") and the Nigerian case law, which is relevant to the case. The court reached its decision on the following grounds.

(a) The Legal Capacity to Enter into Foreign Relations Bayelsa State has no legal powers to conduct foreign relations for and on behalf of itself because "external affairs" are exclusively reserved to the Federal government.

(b) A Certificate from the Secretary of State The Secretary of State for the Foreign and Commonwealth Office had issued a certificate under section 21 of the 1978 Act dated 26 September 2005, which records that:

The Federal Republic of Nigeria is a State for the purposes of Part 1 of the Act, Bayelsa is a constituent territory of the Federal Republic of Nigeria, a federal state for the purposes of Part 1 of the Act. (The claimant) is the 
Governor and Chief Executive of Bayelsa State and is not to be regarded for the purposes of Part 1 of the Act as Head of State of the Federal Republic of Nigeria.

(c) The Functions of Member Statesand the Federal Government That the Nigerian Constitution shows that the States such as Bayelsa State do not have any powers in respect of a number of matters which would normally be associated with a sovereign state.

(d) Limited Powers of Federal Sub-States That there are provisions in the Nigerian Constitution, which show limited powers of federal sub-states such as Bayelsa State in relation to the Federal Republic of Nigeria.

On relevant Nigerian case laws, the court considered the Supreme Court decision in the case of Attorney-General of the Federation of Nigeria v. Attorney-General for Abia State (2001), 11 NWLR where it was held that federal states, such as Bayelsa, are not sovereign states. In that case, the defendants were the Attorney-General for all the sub-states in Nigeria, including Bayelsa State. It was stated in the judgment of the court that "the defendants in the action are not persons within the scope of international law not being sovereign states" (per Ogundare JSC at page 749C) and that "it is certainly not true that the "state" referred to in international conventions refer to our provinces that we conveniently call States". The court also considered the judgment in a more recent Supreme Court case of Attorney-General of the Federation of Nigeria v. Attorney-General of Abia State (No. 2) (2002) 6 NWLR where Chief Justice Uwais said that "the 36 constituent states of Nigeria are not members of the comity of Nations and so the provisions of international law do not directly apply to them but the Federation" (pages 728-729).

\section{REFORMING CONSTITUTIONAL IMMUNITY CLAUSE IN NGERIA}

The immunity granted by the 1999 Constitution is not absolute. The Constitution does not intend to grant the specified officials immunity forever from civil and criminal proceedings in respect of any civil wrong or criminal offence allegedly committed during the tenure of their office. Once their tenure expires civil or criminal proceedings could be 
commenced against them. Thus, immunity merely suspends liability.

In Dasuki v Muazu, ${ }^{115}$ the former military Governor of Sokoto State contended that because of the immunity granted by the Constitution, he could not be held liable for acts done in his official capacity as Military Governor of Sokoto State. The Court of Appeal rejected this contention and held that the constitutional immunity applied only to protect him while in office and that he remained liable for such acts and enjoys no further protection after he left office. This explains why the constitution in its proviso to Section 308(1) states in ascertaining whether any period of limitation has expired for the purpose of any proceedings against a person to whom this section applies, no account shall be taken of his period in office. In other words, to determine whether an action is statute barred, the period of office is not counted. ${ }^{116}$

Also, an incumbent so protected by Section 308 of the Constitution is immune from civil and criminal actions, arrest or imprisonment in pursuance of a court process or from any court process, compelling or requiring his attendance, ${ }^{117}$ but a civil action could be brought against the named public officers in their official capacity or as a nominal party. ${ }^{118}$ The immunity is also limited only to the period of office. This is why, to determine whether any period of limitation has expired for the purpose of any suit against the immune person, no account is taken of the period of office. ${ }^{119}$ It is also important to note that the police or other agencies of government can investigate the public officerswhile they are still in office. The EFCC recently froze the account of Mr Ayo Fayose, the Governor of Ekiti State, arguing that S308 had not been violated as the freezing of the account was in pursuance of their investigation and does not have anything to do with prosecution which they agree was immutable. Protected officials are also not protected for acts outside the country, as the immunity has no extra-territorial application. It is only the President that enjoys protection under the international doctrine of Sovereign Immunity. Such immunity is not extended to the Governors of constituent states in a federation.

115 (2002)16 NWLR (Pt. 793) 319.

116 ICS (Nig) Ltd $v$ Balton B.V.

117 S. 308(1) of the 1999 Constitution.

118 S. $308(2)$, id.

119 S. 308(1) (a) \& (3), id. 
In view of the events of the recent past where the DSS became the Agency of government fighting corruption, the argument that the immunity clause should be totally expunged from the Constitution cannot be supported. If executive immunity is removed, given the excessive control wielded by the President over prosecution machinery like the Police, EFCC, the ICPC, Code of Conduct Bureau, the DSS and other agencies, the Governors can suffer intense harassment from the President due to political differences that he may have with them. ${ }^{120}$

From all indications, therefore, the purpose and extent of the immunity clause is to allow an incumbent completely to have a free hand and mind in the performance of the duties and responsibilities assigned to the office, which he or she holds under the Constitution. But this is not intended to grant him or her immunity forever from full criminal investigation or any criminal proceedings in respect of an offence allegedly committed by him or her during the tenure of office. Immunity is meant to provide a conducive atmosphere where public functionaries can work without any distraction of litigation or hindrance by any service of any court process. ${ }^{121}$ Secondly, the immunity is essentially for the protection of the majesty and dignity of the office not for the individual incumbent as such. To drag an incumbent to court and expose him to the process of examination or crossexamination would degrade the office.

The power of impeachment bestowed on the Legislature to get the protected officials removed from office when case(s) of misconduct bothering on criminality or financial mismanagement are established against them is very potent. Legislators should be completely independent and free from executive influence. This will enable them to hold the Governors and Presidents accountable to the people because they will not condone or cover up a Governor or President who has committed a criminal act or civil wrong. The power of impeachment would be a potent weapon against a corrupt but protected public official. Nigerians should be advised to insist that only credible and honourable men are elected to preserve the dignity and integrity of people elected to the highest offices. This will go a long way in curbing corruption.

120 G. Omoarishe, "Reconsidering Executive Immunity under the Nigeria Constitution" (2007-2010) Nigeria Current Law Review299; A.G. Anambra V.A.G. Federation \& 35 (2005) 7 MJSC 1.

121 J.A. Yakubu,Constitutional Law in Nigeria (Nigeria, Demyax Law, 2003)13. 


\section{CONCLUSION}

The legislative intent for providing constitutional immunity clauses in most commonwealth jurisdictions is to protect the dignity and integrity of the holder of an elective office. This intention is particularly more fundamental and essential in Nigeria given the fledgling and emerging nature of the nation's democratic institutions. Removing the immunity clause could open a floodgate of frivolous litigations against elected officers especially from "professional litigants" with the sole aim and objective of distracting the officer from the very serious business of governance.

The investigation of the activities of the incumbent office holders should continue as it does not conflict with the provisions of the section and they can be made to answer to these investigations as soon as they leave office.However, constitutional immunity should not be extended to the legislative arm of government because such immunity does not avail the third arm of government - the judiciary. More importantly, all the members of the legislature are equal upon being elected. The leaders become primus inter pares upon election to leadership positions and can be removed anytime and substituted by another member without or with minimal disruption to legislative business.

Furthermore, the process of removal from office of protected officers as provided for in the Constitution should be used in proven cases of breach of trust, corruption or mismanagement. The officer concerned can be made to face charges as soon as they are lawfully removed from office as the immunity will abate immediately. 